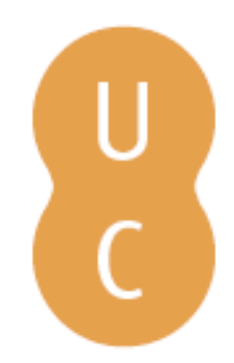

\title{
pommalina
}

\section{Evaluation of wildfire danger in the Peruvian Andes: first step for its reduction and adaptation}
Autor(es):
Manta, Maria I.; Kometter, Roberto; Navia, Alexis
Publicado por: Imprensa da Universidade de Coimbra
URL
persistente:
URI:http://hdl.handle.net/10316.2/44521
DOI:
DOI:https://doi.org/10.14195/978-989-26-16-506_4
Accessed : $\quad$ 26-Apr-2023 10:29:06

A navegação consulta e descarregamento dos títulos inseridos nas Bibliotecas Digitais UC Digitalis, UC Pombalina e UC Impactum, pressupõem a aceitação plena e sem reservas dos Termos e Condições de Uso destas Bibliotecas Digitais, disponíveis em https://digitalis.uc.pt/pt-pt/termos.

Conforme exposto nos referidos Termos e Condições de Uso, o descarregamento de títulos de acesso restrito requer uma licença válida de autorização devendo o utilizador aceder ao(s) documento(s) a partir de um endereço de IP da instituição detentora da supramencionada licença.

Ao utilizador é apenas permitido o descarregamento para uso pessoal, pelo que o emprego do(s) título(s) descarregado(s) para outro fim, designadamente comercial, carece de autorização do respetivo autor ou editor da obra.

Na medida em que todas as obras da UC Digitalis se encontram protegidas pelo Código do Direito de Autor e Direitos Conexos e demais legislação aplicável, toda a cópia, parcial ou total, deste documento, nos casos em que é legalmente admitida, deverá conter ou fazer-se acompanhar por este aviso. 


\section{ADVANCES IN}

\section{FOREST FIRE RESEARCH}

\section{8}

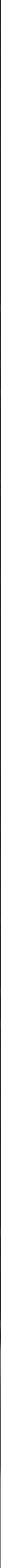




\title{
Evaluation of wildfire danger in the Peruvian Andes: First step for its reduction and adaptation
}

\author{
Maria I. Manta ${ }^{1}$; Roberto Kometter ${ }^{2}$; Alexis Navia ${ }^{1}$ \\ ${ }^{1}$ Universidad Nacional Agraria La Molina. Avenida La Universidad S/N, Apartado 12-056, Lima, \\ Peru, ORCID 0000-0002-4467-9778 \{mmanta@lamolina.edu.pe*,20081514@lamolina.edu.pe\} \\ ${ }^{2}$ Helvetas Swiss Intercooperation. Av. Ricardo Palma 857, Miraflores - Lima, Peru, \\ \{roberto.kometter@helvetas.org\}
}

\begin{abstract}
Recent events of extreme wildfires are occurring in different parts of the world. In Peru, climate of fire has also occurred and has caused material and environmental services losses. The population and the ecosystems from the Peruvian Andes have been directly affected by the fire and a greater reduction in the water supply could affect $95 \%$ of the Peruvian population. Taking into account that there are limitations to estimate the fire danger index and aware the population about wildfire occurrences, here wildfire statistics were used to analyze its spatial and temporal trends from 1973 to 2014 and map fire danger for the Peruvian Andes. Wildfires are spread in all departments of the Peruvian highlands (18) and their fire season length has increased from 4 to 12 months in a year: August, September and October are months with the highest occurrence of wildfire, currently. Four departments of the Southern Andes have a very high fire danger class; while two departments of the Northern Andes have a high fire danger class. In these six departments, the total area burned in 42 years has been 201278 ha (93\% of the total burned area). The ecosystems most affected by the fire were grassland (the Puna, the Páramo and Peatlands), natural forests (Dry Forest in Inter-Andean valleys, Dry Mountain Forest and Tropical Montane Cloud forests) and the Andean shrubs. If the government organizations do not prioritize the implementation of strategies to reduce and adapt to wildfires and its occurrence continues, the severity of the fire could intensify on the Andean natural vegetation and its role in climate and hydrological cycle regulation may change dramatically, affecting the socioeconomic development and the welfare of the population.
\end{abstract}

Keywords: Fire danger map, spatial and temporal distribution, material and environmental losses, disasters, Peru

\section{Introduction}

It is well known the role that weather plays in the occurrence of wildfires because it determines the ease of ignition, propagation rates and severity (Benson, et al., 2009, Fujioka et al., 2008). Övergaard et al. (2007) and FAO (2007) complement that wildfires are usually caused by man accidentally or on purpose all over the world, where fire is widely used for land use change, to improve grazing, and to remove cropping residues and other wastes. However, the magnitude of these fires is related to weather conditions, and exacerbated by drought, high air temperatures and wind. Likewise, extreme weather/climatic conditions that occur over a period of time will affect the moisture content of the fuels and therefore the activity of wildfires.

The knowledge of meteorology constitutes the foundation for the development of fire danger weather indices (FDWI). Fire managers around the world use a variety of systems to track and predict fire danger and fire behaviour, at spatial scales that span from local to global extents, and temporal scales ranging from minutes to seasons (Fujioka, et al., 2008).

In all scenarios the representative concentration pathways of greenhouse gas emissions, a warmer climate is predicted by the end of the century; the magnitude of daily maximum temperatures will increase in the near future, and the frequency of this increase will occur every year, instead of 2 to 3 years as calculated in previous studies (IPCC, 2014). Higher temperatures have already been 
recorded in Sydney $\left(47,8^{\circ}\right.$ C) this year, Spain $\left(47,3^{\circ}\right.$ C) in 2017 (Portillo, 2018), and Russia (43,8 ${ }^{\circ}$ $\mathrm{C}$, national maximum) in 2010 (Wahlstron, 2010). The increase of temperature has caused a greater effective

evapotranspiration producing a depletion of the water in the city of Cabo Blanco and Sao Paulo in 2017 (Portillo, 2018) which would affect the wildfire extinction systems. On the other hand, at a regional level, it is expected that droughts will intensify in dry localities due to the reduction of precipitation and / or the increase in evapotranspiration with a medium confidence level; while at a global level the confidence level is low, due to the lack of direct observations (IPCC, 2014). However, unprecedented droughts have been recorded in very humid ecosystems such as those of the Amazon Basin in 2005 and 2010 (Marengo et al., 2012). In addition, extremely dry, warm and strong winds have contributed to numerous wildfires in Australia (Oliveira, 2010).

As the average global surface temperature increases, extreme precipitation is likely to occur in most mid-latitude places; while in the humid tropical regions the events of extreme daily precipitation will increase in the near future. Similarly, on a regional scale, the variability of precipitation related to El Niño-Southern Oscillation (ENSO) is likely to intensify (IPCC, 2014); situation that would increase the amount of live fuel that will then form the litter ready to burn. The large wildfires in Canada (McGrath, 2016), in Indonesia in 2016, 2009 and 1997-1998 (Jolly et al., 2015), in the Northwest of the United States 2016 (Sullivan, 2016), and in Brazil and Peru in 2005, 1997-1998 occurred in relation to ENSO (FAO, 2007); while big wildfires such as Alaska indoor fire complex (2004), Cedro Fire in Southern California (2003), Biscuit Fire in Southwest Oregon (2002) have occurred in a hot and dry climate (Makenzi, 2009).

Other wildfires with catastrophic consequences in the last two decades have been recorded in Portugal (Ferreira, et al. (2017), Russia 2002 (Chubarova, et al., 2009), Russia 2010 (Jolly, et al., 2015), Australia 2013 (Jolly, et al., 2015) and 2009 (Oliveira, 2010), in Chile 2016-2017 and Peru 2016 (Manta, 2018), all of them associated with climate change.

Given the effect of climate change on the activity of wildfires, the Canadian Fire Weather Index "FWI", part of the Canadian Forest Fire Danger Rating System "CFFDRS", has been used to quantify changes in fire activity in various future climate scenarios. Fujioka, et al. (2008) and Camia et al. (2008;) consider that the FWI is a very precise index to identify the current fire danger weather and their projections in the context to climate change due to their physical foundations, which allows it to define the generality, almost universal of the ignition and propagation of wildfires

The study carried out by Mata Reis (1998) determined that there were several dozens of FDWI among static, dynamic, cumulative and non-cumulative in the European regional association of the World Meteorological Organisation (WMO). According to the study, 31 countries had an FWD Index, 21 of them used it in their operating systems, 13 made forecasts, and only one country spreaded the index using mass media. The study also reported that $59 \%$ of the countries (18) did not evaluate the behaviour of the FDWI in the field.

On the other hand, Moffat and Pearce (2013) analyzed the FDWI of New Zealand and England and determined that in some cases these were discredited in the eyes of its users. They pointed out that it was an erroneous and laborious guide especially when the weather data were not to hand. The same authors found that the scientific model of the indices was unknown by the managers, so their results had little value from a perspective of managing the danger information and there was a limited guidance on the applications of the resulting danger classes. Equally disturbing was the lack of use of FDW Index in some sensitive and relatively fire-prone districts where fire danger was assessed, preferably by "gut feeling". In addition, Manta (2003) mentioned that many FDWI had not been validated with wildfire statistics (area of fires and number of fires) so the warnings should be taken with caution. She adds that some indices require computation programs that are not friendly to managers, and the use of different indices prevented the generalization of FWI use. 
Currently, many countries do not have an FDW Index, despite, the recommendations of the WMO (1998) to adopt the FWI. Mexico uses the FWI, but not in an operating system (SEMARNAT, 2002); while countries of Central America do not have one. In South America, some provinces in Argentina use the FWI (Dentoni, et al., 2007); Public Universities of Brazil (Sampaio, 1998, Soares and Paez, 1974) and Peru (Lau, 2017) have researched in the adaptation of the FWI, but its use has not been implemented in an operational way.

In a warm climate the fire season would become extreme and frequent and the less accurate FDWI would present little variation in the high fire danger class throughout fire season. They could also exceed the maximum value on the highest danger class. The misperception that would generate the extreme fire climate, could lead to inadequate warnings about the large-scale fire danger. This was the case of Russia's FWD Index in 2002 (Chubarova et al., 2010) and Australia in 2009 (Tolhurst, 2010).

Unlike fires of natural origin where it is difficult to determine the number of ignitions and their spatial distribution, wildfires caused by man are not random events; they are often located near inhabited nuclei and tend to follow seasonal patterns, so that they can be known with some accuracy. Consequently, it is possible to assess the trends of fire danger on the geographical history of the occurrence of wildfires characterizing the geographical location of human populations and their production systems. Thus new definition of fire danger comes from the conceptual model of disaster risk management of Hyogo Framework for Action (ISDR, 2005) and the unified procedure for global risk management (ISO 31000, 2009).

The Andes is the longest mountain range on the Earth and is home to more than $75 \%$ of the world's tropical peaks and forms part of the structure and functioning of climate and hydrological cycle. The glaciers store, maintain and bring out the availability of fresh water for human life, natural vegetation and also produce hydroelectric power. The melting of the Andean glaciers contributes to the water flow of 62 rivers of the Pacific slope that supply with water to $95 \%$ of the Peruvian population. Likewise, the Amazon river (was born in the Andes) provides water to the population of the Amazon basin because it is the widest and the largest river on the planet. The Andean natural vegetation has different water yield and maintains infiltration capacity and moisture retention of soils. This is the case of wetlands (tropical Peatlands) that provide $7000 \mathrm{M}$ of $\mathrm{m} 3$ of water per year. Also, Andean soils constitute a natural reservoir of water (Vonk, 1988). Unfortunately, the Peruvian glaciers have fallen by $42 \%(871 \mathrm{~km} 2)$ in a period of 40 years (Santillán, 2015) as a possible result of the increase in air temperature and transport of black coal produced by burning of biomass from the Amazon to the Central Andes (Andrade et al., 2015).

Taking into consideration that government administrations in Peru have limitations in the estimation of FDW Index; which occupies the 23rd position in exposure to climate change (Corporación Andina de Fomento, 2014) and the occurrence of wildfires of disastrous consequences in 2016, the objectives of this study were:

a) Determine the spatial distribution of wildfires in 18 departments of the Peruvian highlands in the last 42 years.

b) Determine the temporal distribution of wildfires in the last 42 years, in 18 departments of the Peruvian highlands.

c) Determine the consequences of wildfires on man and their livelihoods, and on Andean forest ecosystems, and

d) Map out fire danger in the Peruvian Andes.

The knowledge of fire danger distribution in the Peruvian Andes must contribute to planning the strategies of reduction and adaptation to wildfires, guaranteeing that resources will be directed to areas with the greatest danger. 


\section{Methodology}

\subsection{Area of study}

The study area includes 18 departments of Peru with altitudes above 2000 m.a.s.l. The study area was $39,2 \mathrm{M}$ ha (31,8\% of the national territory) where approximately $16,8 \mathrm{M}$ inhabitants live (Instituto Nacional de Estadística e Información "INEI", 2015). The population that lives in five of the departments studied (Amazonas, Apurimac, Ayacucho, Cajamarca, and La Libertad) is characterized by having the highest incidence of poverty in the Peruvian Andes.

According to the Ministry of Environment (2015), natural vegetation of the Andes covers 26,2\% of the national surface. The predominant landscape is the Andean Puna (14,2\%), followed by the Andean Shrub (5,9\%), the Tropical Montane Cloud Forest (3,2\%), the Cardonales (2\%), tropical Peatland $(0,4 \%)$, the Dry Forest of Inter-Andean Valley $(0,34 \%)$ and the Páramo $(0,2 \%)$. Unfortunately, these ecosystems, legally protected or not, are intentionally burned to change the use of forest and protection lands to agricultural, mining and illicit crops, mainly.

\subsection{Main definitions}

Using the Regulation of Natural Land Use Capacity ( ${ }^{\circ}$ 062/1975-AG), Manta and León (2004) define wildfire as the uncontrolled fire that affects the wild vegetation that grows on forest and on protection lands, anywhere within the national territory.

In this research fire danger was defined as the potential occurrence of an event or physical tendency of wildfires of human or natural origin, which can cause loss of life, injury, impairment of livelihoods and negative effects on human health; loss of ecosystems, environmental resources, provision of services, as well as damages and losses in properties and infrastructure (modified from ISDR, 2005). In different circumstances, a generalized interruption and damage to a community that exceeds its ability to cope through the use of its resources is defined as catastrophe or disaster (Mayner and Arbon, 2015).

\subsection{To identify fire danger, the following procedure was followed}

a) The background of wildfires in 18 departments of the Peruvian Highlands was collected, reviewed, and a study period of 42 years was defined (1973 to 2014). The information came from government institutions with competencies in wildfire, the Universidad Nacional Agraria La Molina, other research centres, as well as news from local and national newspapers, radio and virtual networks.

b) The information regarding to wildfires occurrence was ordered and classified in order to create a wildfire database in Excel (2000).

c) To know the spatial distribution of the number of wildfires, the extent of area affected by fire, the consequences on man and their livelihoods, on the Andean vegetation, as well as the causes of wildfires, a record format was designed in Excel (2000).

d) To know the temporal distribution of wildfires, the date of wildfires occurrences was analyzed.

e) The geographic location of populations within of each department was established, through the use of information from the INEI (2015).

\subsection{The fire danger rating}

The fire danger rating across the studied departments was determined on the basis of area of wildfires occurred in each department and its historical-geographical location in relation to the total area affected by fire in the period studied (Table 1). 
Table 1 - Threshold values of area burned defining fire danger classes

\begin{tabular}{lcl}
\hline Class & Area affected by wildfires (ha) & \multicolumn{1}{c}{ De finition } \\
\hline Very high & $\geq 25000$ and $<75000$ & $\begin{array}{l}\text { The department has from } 10 \text { to } 35 \% \text { of total area } \\
\text { affected by wildfires over } 42 \text { years }\end{array}$ \\
High & $\geq 10000$ and $<25000$ & $\begin{array}{l}\text { Ihe department has trom } 5 \text { to }<10 \% \text { of total area } \\
\text { aftected by wildfires over } 42 \text { years }\end{array}$ \\
Medium & $\geq 1000$ and $<10000$ & $\begin{array}{l}\text { The department has from } 1 \text { to }<5 \% \text { of total area } \\
\text { affected by wildfires over } 42 \text { years }\end{array}$ \\
Low & $\geq 0,01$ and $<1000$ & $\begin{array}{l}\text { The department has from } 0,01 \text { to }<1 \% \text { of total area } \\
\text { aftected by wildtres over } 42 \text { years }\end{array}$ \\
\hline
\end{tabular}

\section{Results and discussion}

Wildfires are spatially distributed in all departments studied (18) in the period 1973-2014. In departments of Tacna and San Martín, wildfires occurred, but it could not be quantified due to lack of written evidence. Wildfires occurred in all provinces of departments of Cusco and Apurímac; in 10 departments, wildfires have occurred in more than $50 \%$ of their provinces. At the district level, in departments of Cusco, Apurímac and Puno in 63\% (68), 63,3\% (50) and 26\% (28) of their districts respectively, wildfires have occurred; while in 13 departments, from $20 \%$ to 2,3\% of theirs districts have had wildfires (Table 2). The wide spatial distribution of wildfires could be the fact that the main cause of wildfires is livestock activity (60\%), followed by agriculture (30\%) and mining. In these activities, fire is used to clear lands due to it is the most economical tool.

Table 2 - Spatial distribution of wildfires in the Peruvian Andes. Period 1973-2014

\begin{tabular}{clrrrrrr}
\hline $\mathbf{N}^{\circ}$ & Department & $\begin{array}{r}\text { Provinces } \\
\left(\mathbf{N}^{\circ}\right)\end{array}$ & $\begin{array}{r}\text { Provinces with wildfires } \\
\left(\mathbf{N}^{\circ}\right)\end{array}$ & $\begin{array}{r}\text { Districts } \\
(\mathbf{\%})\end{array}$ & $\begin{array}{r}\text { Districts with wildfires } \\
\left(\mathbf{N}^{\circ}\right)\end{array}$ & $\begin{array}{r}(\%) \\
(\mathbf{N})\end{array}$ \\
\hline 1 & 13 & 13 & 100,0 & 108 & 68 & 62,0 \\
2 & Cusco & 13 & 10 & 76,9 & 108 & 28 & 25,9 \\
3 & Arequipa & 8 & 6 & 75,0 & 108 & 22 & 20,4 \\
4 & Apurimac & 7 & 7 & 100,0 & 79 & 50 & 63,3 \\
5 & Cajamarca & 13 & 8 & 61,5 & 127 & 19 & 15,0 \\
6 & Piura & 8 & 3 & 37,5 & 62 & 5 & 8,1 \\
7 & Ancash & 20 & 10 & 50,0 & 166 & 12 & 7,2 \\
8 & Ayacucho & 11 & 7 & 63,6 & 111 & 15 & 13,5 \\
9 & Junin & 9 & 6 & 66,7 & 123 & 8 & 6,5 \\
10 & Amazonas & 7 & 4 & 57,1 & 83 & 7 & 8,4 \\
11 & Pasco & 3 & 2 & 66,7 & 28 & 3 & 10,7 \\
12 & Huancavelica & 7 & 4 & 57,1 & 93 & 4 & 4,3 \\
13 & La Libertad & 12 & 2 & 16,7 & 82 & 2 & 2,4 \\
14 & Huánuco & 11 & 3 & 27,3 & 75 & 3 & 4,0 \\
15 & Lima & 10 & 4 & 40,0 & 171 & 4 & 2,3 \\
16 & Moquegua & 3 & 2 & 66,7 & 20 & 4 & 20,0 \\
\hline
\end{tabular}

Every year fire danger is present in Cusco since 1973 (42 years); while in Apurímac the danger would have been present for 20 years (Table 3). Furthermore, Huánuco has the lowest number of years 
with wildfire activity and in five departments fire occurrence is five years old. However, this result should be taken with caution because the lack of written records does not mean that there have not been wildfires. National awareness of wildfire began by the 2016 fire season because the high-impact wildfire, which threatened critical communities and infrastructure. This is the reason why they have not record the incidents of wildfire systematically and no have a complete statistic at the national level.

Table 3 - Characteristics of wildfires in departments of the Peruvian Andes

\begin{tabular}{rlrrrrrrr}
\hline $\mathbf{N}^{\circ}$ & Department & $\begin{array}{c}\text { Years with } \\
\text { wildfires }\end{array}$ & \multicolumn{1}{c}{$\begin{array}{c}\mathbf{N}^{\circ} \text { of } \\
\text { fires }\end{array}$} & \multicolumn{2}{c}{$\begin{array}{c}\text { Area of fires } \\
\text { (ha) }\end{array}$} & \multicolumn{1}{c}{ (\%) } & \multicolumn{2}{c}{$\begin{array}{c}\text { Population } \\
\text { Poor }\end{array}$} \\
\hline Extrem poor & \multicolumn{1}{c}{ Total } \\
\hline 1 & Cusco & 42 & 313 & 71040,29 & 32,79 & 646838 & 262026 & 1265827 \\
2 & Puno & 11 & 132 & 48535,90 & 22,34 & 815136 & 347237 & 1340684 \\
3 & Arequipa & 12 & 63 & 27682,90 & 12,74 & 222984 & 33749 & 1205317 \\
4 & Apurimac & 20 & 249 & 26078,36 & 12,0 & 312274 & 179013 & 444202 \\
5 & Cajamarca & 8 & 42 & 14905,58 & 6,86 & 836169 & 371797 & 1493159 \\
6 & Piura & 5 & 10 & 13035,01 & 6,00 & 694897 & 168460 & 1754791 \\
7 & Ancash & 12 & 81 & 6633,48 & 3,05 & 349602 & 91008 & 1109849 \\
8 & Ayacucho & 11 & 22 & 4189,53 & 1,93 & 402500 & 168459 & 642972 \\
9 & Junin & 12 & 506 & 2549,01 & 1,17 & 443269 & 129233 & 1292330 \\
10 & Amazonas & 10 & 19 & 1874,04 & 0,86 & 245804 & 102761 & 411043 \\
11 & Pasco & 13 & 112 & 392,03 & 0,18 & 160928 & 69425 & 290483 \\
12 & Huancavelica & 4 & 5 & 210,03 & 0,1 & 364168 & 220765 & 471720 \\
13 & La Libertad & 3 & 3 & 60,01 & 0,03 & 671054 & 222535 & 1725075 \\
14 & Huánuco & 2 & 3 & 40,01 & 0,02 & 528628 & 267182 & 819578 \\
15 & Lima & 3 & 5 & 27,51 & 0,01 & 1246745 & 64766 & 8095747 \\
16 & Moquegua & 5 & 9 & 25,33 & 0,01 & 32687 & 6267 & 169365 \\
17 & San Martin & N.D. & N.D. & N.D. & N.D. & 340020 & 92523 & 771021 \\
18 & Tacna & N.D. & N.D. & N.D. & N.D. & 55218 & 5049 & 315534 \\
Total Andes & & $\mathbf{1 5 7 4}$ & $\mathbf{2 1 7 2 7 9 , 0 2}$ & $\mathbf{1 0 0 , 0 0}$ & $\mathbf{8 3 6 8 9 2 2}$ & $\mathbf{2 8 0 2 2 5 3}$ & \\
\hline
\end{tabular}

N. D.: No Data

The annual occurrence of wildfire shows an accelerated increase over 42 years in almost all the departments studied. The annual increase, both in the number of wildfires and area of fires (Figure 1), can be explained by a greater use of fire in livestock and agricultural activities (two annual harvests) generated by market demand (Defries, et al., 2010), as well as the change in the use of forest and protection lands for agricultural use. But, the higher temperatures associated with the humidity deficit generated a greater flammability of dead and living biomass, with the consequent increase in size of wildfires. Also, this increase would be the result of the ENSO of 1994 and 1998, as well as the droughts that occurred in 2005 and 2010. The average burned area in each decade confirm this trend (Figure 2). 


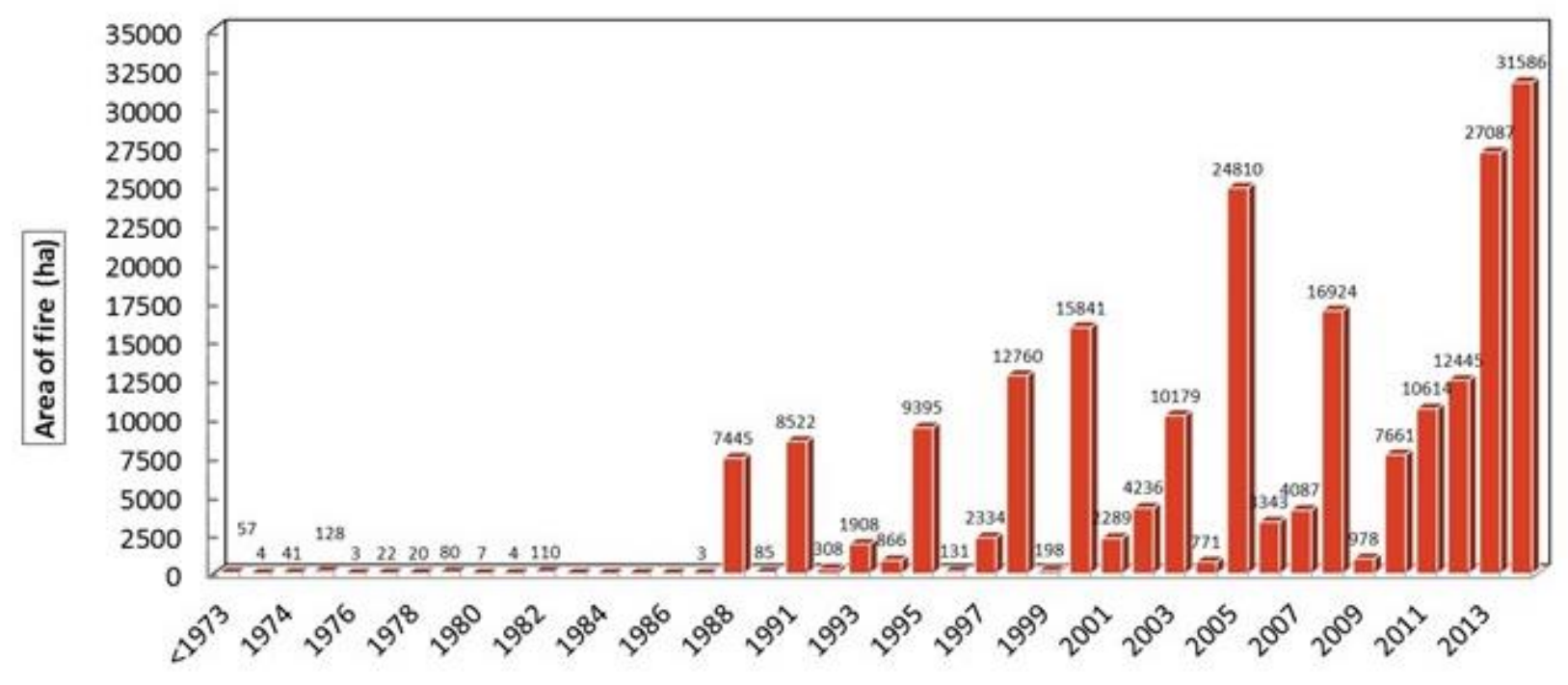

Figure 1 - Distribution of the annual area of fire in the Peruvian Andes

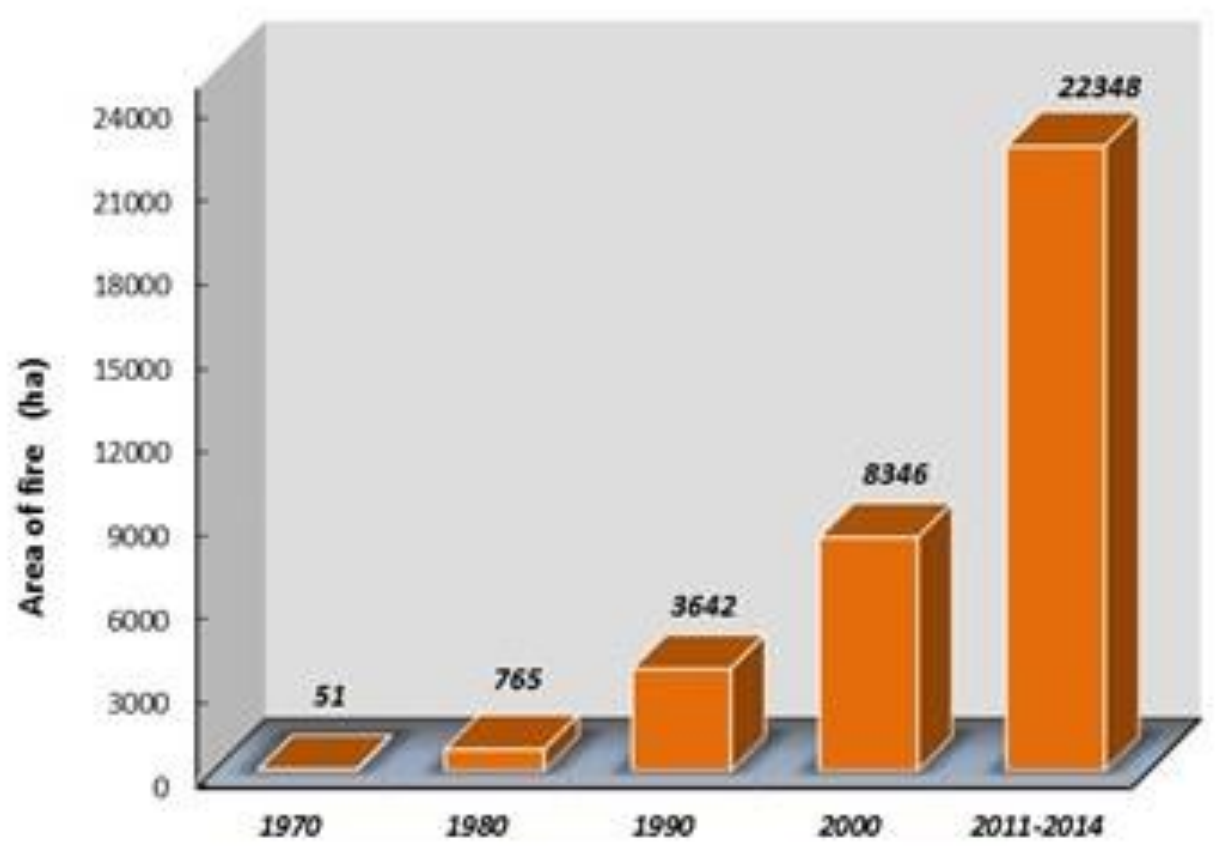

Figure 2 - Average of area burned by decades. Period: 1973-2014.

The temporal analysis of the number of wildfires in a calendar year, determined an increase in the number of months with wildfires. During 1973 to 2004 the fire season length comprised four months (from July to October); during the period 2005 to 2007 the season lasted seven months (from May to November). In the period from 2008 to 2014, the wildfire season length was extended to 12 months; although in December and January, as well as from February to May, the number of wildfires and the area of fire was low. This result suggests a collapse in the resources of extinction available to departments. On the other hand, this result reveals the consistency of the forecasts made by Jolly, et al. (2015) on the global wildfire danger.

The spatial and temporal distribution of wildfires in 18 departments threatens 11,2 million poor and extreme poverties Peruvians. The total Lima's population has been excluded because they are living in the capital of the department (Table 3). The threatened population has a low Human Development 
Index (between 0,2 to 0,4); they do not know the means to stop causing IF, to prevent them, as well as to handle the consequences of them. This situation makes them vulnerable to FIs and other natural hazards that they face year after year. The geographic location of the occurrences of the FIs will make it possible to take protective measures, carry out preventive actions, pre-suppression, suppression and rehabilitation of the affected areas in the localities, districts and provinces where IF occurs.

The spatial and temporal establishment of wildfires in the Peruvian Andes has produced material and environmental losses. During 1995-2014, 24 farmers died mainly, when they were trying to put out wildfires. In addition, on average each year, 7 people suffered accidents in the extinction activities; in the same way, 2317 people lost their homes and 6593 people were left with homes partially because the fire. Since medical statistics are not available in most departments, it has not been possible to estimate the number of people treated for respiratory diseases. Nevertheless, each year $\mathrm{CO}_{2}$ emissions affect human health, climate and contribute to glaciers retreat.

In the last 42 years, at least 1574 wildfires have occurred in the Peruvian highlands, causing loss and deterioration of $0,2 \mathrm{M}$ ha of natural Andean vegetation cover. The effect of fire on the Andean vegetation has depended on their sensitivity to fire, the frequency of wildfires, as well as the duration and severity of the fire. Similarly, the degree of deterioration of Andean soils depended on the type of fire, the severity and frequency of the fire, the associated production practices, as well as climate. The ecosystems most affected by the fire were: The Andean Puna and the Páramo (61\%), the Natural Forests (9\% of (Dry Forest in Inter-Andean valleys, Dry Mountain Forest and Tropical Montane Cloud forests), the Andean shrubs (1,4\%) and the tropical Peatland (1,3\%), as shown in the Figure 3. However, $26 \%$ of the area of fire could not be classified due to lack of information. The scarce forest plantations in the country were also affected in $0,8 \%$ (1726 ha) of its surface.

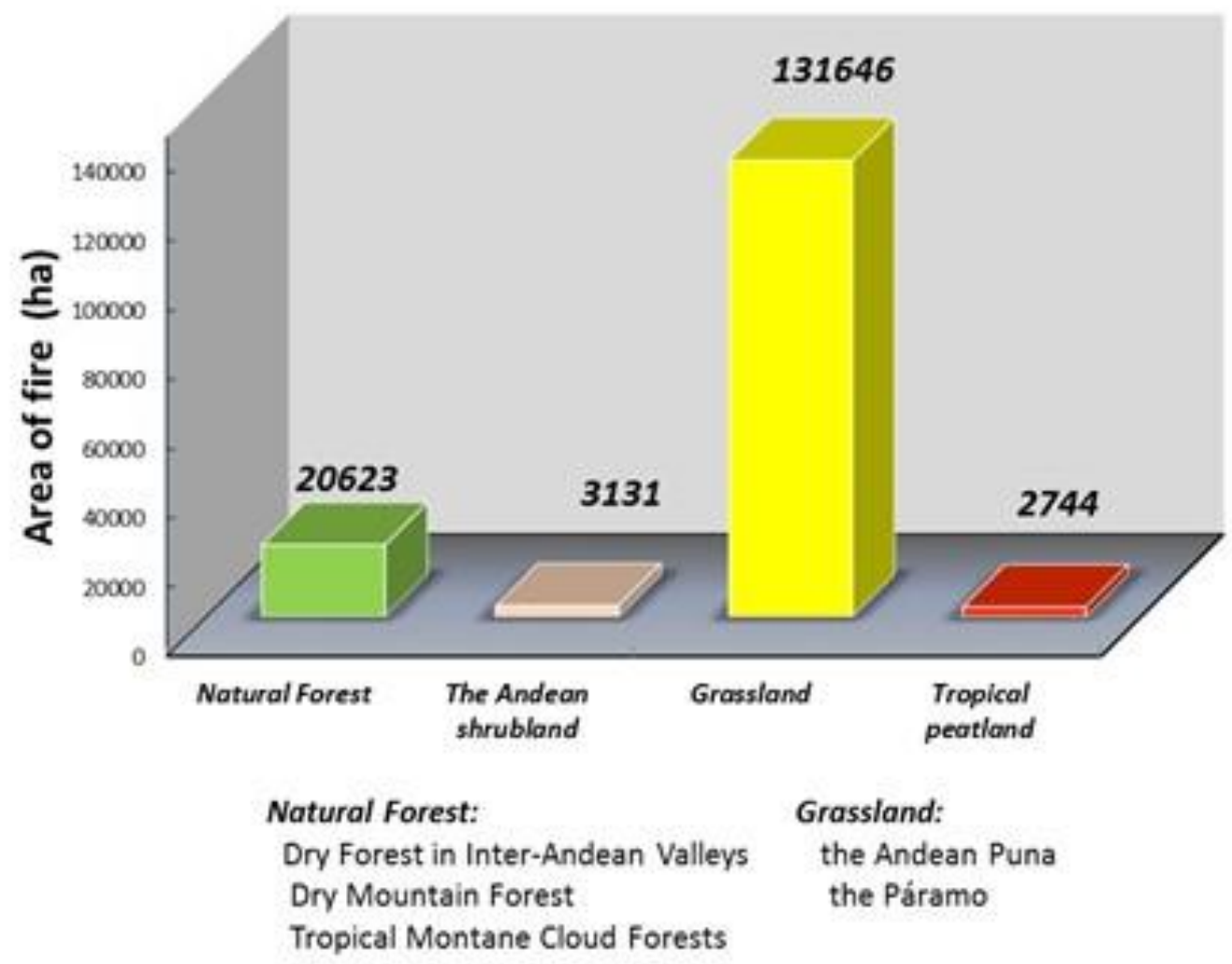

Figure 3 - Different vegetation types affected by wildfires in the Peruvian Andes

Loss of vegetation cover and forest and protection soils implies loss of $\mathrm{CO} 2$ retention capacity, contributing to global warming. Likewise, the reduction of the Andean Puna, the Páramo and the 
tropical Peatland would be generating decrease of rivers flow in Apurímac, Huancavelica and Ayacucho, in the last years. According to Arroyave (2007), the Páramo is the ecosystem with the highest average water yield (63\% of total flow/precipitation); next in importance is the Andean forest with 57\% average water yield (Tobón and Arroyave, 2008); while Murphy and Lugo (1986) affirmed that the tropical dry forest had the lowest water yield (19\%). Rapid assessment of the economic valuation of material losses and environmental services let SERFOR and AGRORURAL (2016) affirm that it reaches an average annual loss per department of US \$ 2,1 M and US \$ 4,6 M respectively.

Unfortunately, it is believed that the Andean ecosystems have the capacity of recover to the fire and other types of disturbious. The Tropical Montane Cloud Forests, Dry Forest in Inter-Andean valleys and Dry Mountain Forest, are not adapted to fire (Páramo, 2011), so the regeneration capacity and return to original conditions is very low. Meanwhile, The Andean Puna and the Páramo are adapted to fire because they have lived with it for centuries (Myers, 2007); however, frequent and severe wildfires and other human disturbances are altering their resilience.

This study presents, for the first time, the fire danger map for the Peruvian Andes (Figure 4). The very high danger class is found in four departments in the south of the country (Cusco, Puno, Arequipa and Apurímac) that represent $80 \%$ of the area affected by fire in 42 years; two of them have a high fire danger class and represent $13 \%$ of the burned area (Cajamarca and Piura); three departments have a medium fire danger class and represent $6 \%$ of the burned area (Ancash, Ayacucho and Junín); while, seven departments have a low fire danger class since the area affected by the fire reached $1 \%$ of the total burned area (Amazonas Pasco, Huancavelica, La Libertad, Huánuco, Lima and Moquegua).

The fire danger in the Peruvian Andes can be explained through the sociological, weather and vegetation cover variables. The use of fire in livestock and agricultural activities is a major component of fire danger; the weather variable contributes to explain a greater severity of wildfires due to the decrease in rainfall from North to South which is manifested in the area affected by the fire. When the vegetation map is overlaid with the fire danger map, it is observed that the surface most affected by fire corresponds to the Andean Puna of the Southern Highlands due to the flammability of dead and living biomass and the rate of fire spread in the large and rugged area that it occupies.

According to the fire danger map, it is expected that the next fire seasons, severity of fire will intensify over the same localities, for which, the managers involved should make sure to prevent and prepare the society and the territory to respond and recover from wildfires.

\section{Conclusion}

The statistics of the area affected by the fire have allowed us to show spatially and temporally wildfires occurrences and establish four fire danger classes in the Peruvian Andes.

According to the fire danger map, 56,2\% (9) of the departments studied have values that are in a very high, high and medium classes. These departments should be of interest in the implementation of strategies to reduce and adapt to fire danger. Priority should be given to six departments with very high and high classes of fire danger, which reach $93 \%$ of total area of fire in the period studied. The very high fire danger class is present in four 


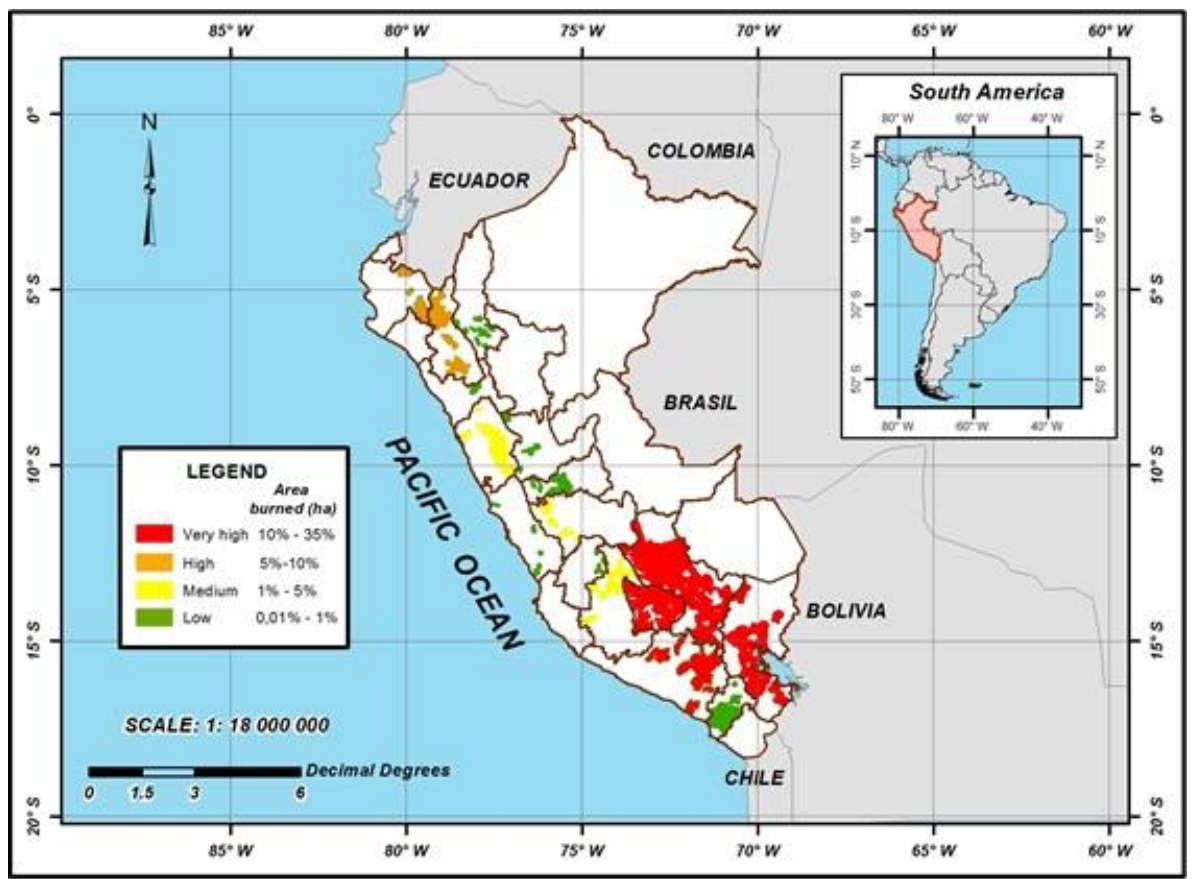

Figure 4 - Fire danger map for the Peruvian Andes

departments located in the Southern Highlands of the country, while the high fire danger class is present in two departments of the North Highlands of the country.

The vegetation most threatened by wildfires is the grasslands. The danger increases in the Páramo and the Peatland because they have a small surface and because they lose their water efficiency. If the occurrence of wildfires continues, the Andean vegetation will disappear and with this, the regulation of climate and hydrological cycle will have changed, affecting socio-economic development and wellbeing of Peruvians.

\section{References}

Arroyave, F. 2007. Contribución de la precipitación horizontal al ciclo hidrológico de los páramos, con referencia inicial al páramo de Guerrero. Tesis Mg. Sc. Universidad Nacional de Colombia. Medellín. 112 p.

Andrade, M., Zaratti, F., Laja, P., Wiedensohler, A., Krejci, R., Whiteman, N., Ramonet, M., Calzolari, F., Vuillermoz, E., Rose, C. 2015. Transporte de carbón negro hacia los glaciares centrales Andinos. In Andes regional conference: mitigating open agricultural burning. International Criosfera climatic initiative (ICCI), Molina Center, Autoridad Nacional del Agua and CONDESAN. 12 y 13 de febrero, Lima, Perú.

Camia, A., Amatulli, G., San-Miguel-Ayanz, J. 2008. Past and future trends of forest fire danger in Europe. Luxembourg: Office for Official Publications of the European Communities. UR Scientific and Technical Research Series - ISSN 1018-5593.

Benson, R., Roads, J., Weise, D. 2009. Climatic and weather factors affecting fire occurrence and behavior. Developments in Environmental Science 8, 37-60.

Chubarova, N., Prilepsky, N., Rublev, A., Riebau, A. 2009. A Mega-fire event in Central Russia: fire weather, radiative, and optical properties of the atmosphere, and consequences for Sub Boreal forest plants. Developments in Environmental Science, 8, 247-264.

Corporación Andina de Fomento. 2014. Índice de vulnerabilidad y adaptación al cambio climático en la región de América Latina y el Caribe. 211 p. 
DeFries, R.; Rudel, T., Uriarte, M., Hansen, M. 2010. Deforestation driven by urban population growth and agricultural trade in the twenty first century. Nature geosciences 3;178-181.

Dentoni, M. Muñoz, M., Epele, F. 2007. Implementación de un sistema nacional de evaluación de peligro de incendios: la experiencia argentina. In 4ta Conferencia Internacional de Incendios Forestales. 2007. Editado por R. Veléz. Sevilla, España.

Estrategia Internacional para la Reducción de Desastres (EIRD). 2005. Marco de Acción de Hyogo para 2005-2015. In Conferencia Mundial sobre la Reducción de los Desastres. 18 a 22 de enero de 2005, Kobe, Hyogo, Japón. Naciones Unidas, Ginebra. Suiza. 22 p.

FAO. 2007. Fire Management Global Assessment 2006. FAO, Forestry Paper $N^{\circ} 151$. A Thematic study prepared in the framework of the Global Forest Resource Assessment 2005. Rome, Italy. 121 p. ISSN.0258-6150.

Ferreira-Leite, F., Ganho, N., Bento-Gonçalves, A., Botelho, F. 2017. Iberian atmospheric dynamics and large forest fires in mainland Portugal. Agricultural and Forest Meteorology 247 (15):551-559.

Fujioka, F, Malcolm, A, Viegas, d., Mike, b. 2008. Fire Danger and Fire Behavior Modeling Systems in Australia, Europe, and North America. Developments in Environmental Science, 8, 471-497.

INEI. 2015. Perú: Anuario de Estadísticas Ambientales 2014. Oficina de Impresiones del Instituto Nacional de Estadística e Informática. 573 p.

IPCC, 2014: Climate Change 2014: Synthesis Report. Contribution of Working Groups I, II and III to the Fifth Assessment Report of the Intergovernmental Panel on Climate Change [Core Writing Team, R.K. Pachauri and L.A. Meyer (eds.)]. Geneva, Switzerland. 151 p.

Jolly, W., Cochrane, M., Freeborn, F., Holden, Z., Brown, T., Williamson, G., Bowman, A. 2015. Climate-induced variations in global wildfire danger from 1979 to 2013. Nature Communication, 6,7537 doi: 10.1038/ncomms8537 (2015).

Lau, J. 2017. Utilización del índice meteorológico de incendios forestales (Fire Weather Index) en el departamento de Cusco. Tesis Ing. Meteorológo. Facultad de Ciencias. Universidad Nacional Agraria La Molina 136 p.

McGrath, M. 2016. "Perfect storm" of El Niño and warming boosted Alberta fires". BBC News. May 5 BBC. https://en.wikipedia.org/wiki/2016_Fort_McMurray_wildfire Retrieved Feb 7, 2018.

McKenzie, D., Peterson, D., Littell, J. 2009. Global warming and stress complexes in forests of western North America. Developments in Environmental Science 8.,319-338.

Manta, M. I. 2018. El desafío de preparar a la sociedad ante los incendios forestales. El Ingeniero de Lima (Perú) XXV (83):32-33

Manta, M.I., León, H. 2004. Los Incendios Forestales del Perú: Grave problema por resolver. Floresta (Brasil) 34(2), 179-189.

Manta, M.I. 2003. Estudio de la estructura y funcionamiento de dos índices de peligro meteorológico de incendios forestales. Aplicación a tres zonas climáticas de España peninsular. Tesis Ph. D. Escuela Técnica Superior de Ingenieros de Montes. Universidad Politécnica de Madrid. Madrid, España. 329 p.

Marengo, J., Tomasella, J., Alves, L., Soares, W., Rodriguez, A. 2011. The drought of 2010 in the context of historical droughts in the Amazon region, Geophys. Res. Lett.0 38, L12703, doi:10.1029/2011GL047436.

Marengo, J., Nobre, C., The Drought of Amazonia in 2005. Journal of Climate 21(3), 495-516. 175/2007JCLI1600.1

Mata Reis, R. 1998. Scales for the assessment of forest fire danger. In III International Conference on Forest Fire Research. 14 ${ }^{\mathrm{a}}$. Conference on Fire and Forest Meteorology. Editado por D. Viegas. Luso; Coimbra, Portugal. ADAI. p. 1.235-1.243. 
Mayner, L.; Arbon, P. 2015. Defining disaster: The need for harmonisation of terminology. Australas. J. Disaster. Trauma Stud. 19, 21-26

Ministerio del Ambiente. 2015. Mapa nacional de cobertura vegetal: Memoria descriptiva. Dirección General de Evaluación, Valoración y Financiamiento del Patrimonio Natural. Lima, Perú. 108 p.

Moffat, A., Pearce, H. 2013. Harmonising approaches to evaluation of forest fire risk. NZ TRANZFOR Visit: Final Report. Forest Research, Farnham. 42 p.

Murphy, P.; Lugo, A. 1986. Ecology of tropical dry forest. Annals Review of Ecology and Systematics 17, 67-68

Myers, R. 2007. Conceptos básicos en el manejo integral del fuego. In Taller Internacional Nuevas Estrategias para el Manejo Integral del Fuego en Ecosistemas Tropicales Prioritarios para la Conservación. The Nature Conservancy y ProNaturaleza. Puerto Maldonado, Perú, del 18 al 22 de junio.

Oliveira, R. 2010. Um estudo sobre os incêndios florestais ocorridos no estado de Vitória (Austrália), em fevereiro de 2009. Tese de Mestrado Interdisciplinar em Dinâmicas Sociais, Riscos Naturais e Tecnológicos. Faculdade de Ciências e Tecnologia Departamento de Engenharia Mecânica. Universidade de Coimbra, Portugal. 98 p.

Övergaard, R., Gemmel, P. and Karlsson, M. 2007. Effects of weather conditions on mast year frequency in beech (Fagus sylvatica L.). Sweden. Forestry 80, 555-565.

Páramo, G. 2011. Susceptibilidad de las coberturas vegetales de Colombia al fuego. In Incendios de la Cobertura vegetal en Colombia. Tomo I. Ed. por Álvaro del Campo Parra Lara. Universidad Autónoma de Occidente. Cali, Colombia. p. 73-144.

Portillo, G. 2018. Ciudadanos propone cambios en el Plan Hidrológico Nacional para adaptarse al cambio climático en España. www.meteorologiaenred.com/ciudadanos-propone-cambios-phnadaptarse-al-cambio-climatico.htm. Retrieved January 19, 2018.

Sampaio, O.; Soares, R.; Viegas, D. 1998. Evaluation and test of four methods of forest fire danger in Sao Paulo, Brazil. In III International Conference on Forest Fire Research. 14a ${ }^{\mathrm{a}}$. Conference on Fire and Forest Meteorology. Editado por D. Viegas. Luso; Coimbra, Portugal. ADAI. p.1.249-1.262.

Santillán, N. 2015. Impacto del Cambio Climático en los Glaciares Regionales: Contexto Regional y Nacional. In Andes regional conference: mitigating open agricultural burning. International Criosfera climatic initiative (ICCI), Molina Center, Autoridad Nacional del Agua and CONDESAN. 12 y 13 de febrero, Lima, Perú

Secretaría de Medio Ambiente y Recursos Naturales. 2002. Curso Protección contra incendios Forestales. Formación de instructores. Módulo índice de peligro. México/USAID.

SERFOR, AGRORURAL. 2016. Diagnóstico sobre la situación actual de los incendios forestales en el Perú, con especial referencia a los bosques Andinos. Consultora María Isabel Manta Nolasco, Docente de la Facultad de Ciencias Forestales, UNALM. Financiado por el Programa bosques Andinos del Helvetas Swiss Intercooperation. 168 p.

Soares, R.; Paez, G. 1974. Uma nova formula para determiner o grau de peligro de incedios florestais na Regi ao Centro Paranense. Revista Floresta. Trabajo presentado en el II Congreso Forestal de Brasil.

Sullivan, B. 2016. El Nino added to Alberta's fire woes before Fort McMurray Burned. News. https://en.wikipedia.org/wiki/2016_Fort_McMurray_wildfire .Retrieved April 6, 2018.

Tobón, C., Arroyave, F. 2008. Hidrología de los bosques alto-andinos. En: Ecología de Bosques Andinos. Editado por: León. Universidad Nacional de Colombia. 213 p.

Tolhurst, K. 2010. Report on fire danger ratings and public warning. Department of Forest and Ecosystem Science University of Melbourne, Australia. 26p. 
Vonk, J. 1988. Soil conservation in Peru. In: Conservation Farming on Steep Lands. Edited by Ankeny, IA; Moldenhauer W. and N. Hudson. Soil and Water Conservation Society and World Association of Soil and Water Conservation. New York, USA.

Wahlstron, M. 2010. Ola de calor Rusia y Pakistán, Desastres naturales 2010. http://www.bbc.com/mundo/noticias/2010/12/101221_desastres_naturales_2010_lh. Retrieved May 7,2018.

World Meteorological Organisation. 1994. Systems for evaluation and predicting the effects of weather and climate on Wildland fires. Special Environment Report $N^{\circ} 11$. WMO No 496. Geneva, Switzerland. Secretariat of the World Meteorological Organisation. 34 p. 